\title{
Nederland en kinderhuwelijken
}

\author{
Susan Rutten
}

Actuele maatschappelijke ontwikkelingen en recente onderzoeksbevindingen tonen aan dat Nederland te maken heeft met kinderhuwelijken. In deze bijdrage zal worden onderzocht of de aanpassingen in de Nederlandse huwelijkswetgeving die eind 2015 in werking zijn getreden, bijdragen aan een verbetering van de problematiek van kinderhuwelijken.

\section{Aanleiding}

Sinds een aantal jaren begint in Nederland het besef door te dringen dat Nederland te maken heeft en rekening moet houden met kinderhuwelijken, huwelijken waarbij op het moment van huwelijkssluiting ten minste één van de huwelijkskandidaten de leeftijd van 18 jaar nog niet heeft bereikt. ${ }^{1}$ In 2013 kwam een huwelijk met een minderjarige dat buiten de officiële weg was gesloten in de publiciteit. ${ }^{2}$ De Nederlandse overheid liet nader onderzoek doen naar dergelijke huwelijken in Nederland, hetgeen in december 2015 leidde tot het rapport Gewoon Getrouwd. Een onderzoek naar kindhuwelijken en religieuze huwelijken in Nederland. ${ }^{3}$ Uit dit onderzoek blijkt dat Nederland inderdaad te maken heeft met kinderhuwelijken, zowel gesloten in het buitenland als in Nederland zelf. In 2013 en 2014 zou het gaan om naar schatting circa 250 kinderhuwelijken per jaar. In het najaar van 2015 werd pijnlijk duidelijk dat er zich meerdere kindbruiden bevinden onder de recente stromen asielzoekers die op de vlucht zijn voor onder meer de oorlog in Syrië en de terreur van IS, getrouwd in het land van herkomst of, misschien minstens zo zorgelijk, tijdens de vlucht in vluchtelingenkampen op weg naar Europa. ${ }^{4}$ Een wetsvoorstel uit 2012, ${ }^{5}$ gewijzigd in $2014,{ }^{6}$ tegen huwelijksdwang lag nog ter behandeling door de Eerste Kamer voor, maar werd vanwege de spoedeisendheid van de kwestie versneld aangenomen en trad op 5 december 2015 in werking. ${ }^{7}$ In april 2016 verschijnt een rapport van de Natio-

1 Deze definitie sluit aan bij art. 1 van het VN Kinderrechtenverdrag en die van de Raad van Europa, Parliamentary Assembly, article 7 Resolution 1468 (2005) on Forced Marriages and Child Marriages, 5 oktober 2005, 1468 (2005), te raadplegen via: www.refworld.org/docid/ 43f5d5184.html.

2 O.m. de Volkskrant van 13 mei 2013 maakt melding van een informeel huwelijk tussen een Pakistaans minderjarig meisje en een Pakistaanse jongen.

3 S. Rutten e.a., Gewoon Getrouwd. Een onderzoek naar kindhuwelijken en religieuze huwelijken in Nederland, Den Haag 2015.

4 Rutten e.a. 2015, p. 74; C.E. Dettmeijer-Vermeulen, L.B. Esser \& F. Noteboom, Zicht op kwetsbaarheid, Den Haag 2016, p. 43-44.

5 Kamerstukken II 2012/13, 33488, 2.

6 Kamerstukken II 2013/14, 33488, A.

7 Wet van 7 oktober 2015, Stb. 2015, 354. 
naal Rapporteur Mensenhandel en Seksueel Geweld tegen Kinderen, waarin wordt gesproken over 210 Syrische kindbruiden die bij de Immigratie en Naturalisatie Dienst (IND) werden gemeld in de periode van 24 juli 2014 tot 18 februari 2016, waarbij de IND zelf in de laatste vier maanden van 2015 tot 18 januari 2016 te maken zou hebben gehad met 60 kindbruiden. ${ }^{8}$ De aantallen leiden tot tal van Kamervragen. ${ }^{9}$ Kinderhuwelijken zijn niet langer alleen meer een internationaal, maar ook een nationaal probleem en een nationale zorg geworden. Over het algemeen worden kinderhuwelijken als problematisch gezien en als gevaar voor mensenrechtenschendingen van vooral meisjes. De aard van de kinderhuwelijken alsook de motieven voor en achtergronden van deze huwelijken en de belangen die hierbij in het geding kunnen zijn, kunnen echter nogal uiteenlopen, zeker als buitenlandse en binnenlandse kinderhuwelijken naast elkaar worden gezet.

In deze bijdrage zal worden onderzocht of de wijzigingen in de huwelijkswetgeving van eind 2015 zullen leiden tot een verbetering van de problematiek omtrent kinderhuwelijken. Zal deze wetgeving leiden tot een afname van kinderhuwelijken? Komt de wetgeving tegemoet aan de bestaande zorgen en biedt zij bescherming van de belangen die bij kinderhuwelijken in het geding kunnen komen? Spelen religieuze motieven een rol bij de totstandkoming van kinderhuwelijken en, zo ja, worden gelovigen door de nieuwe wetgeving daarom extra hard getroffen? Begonnen zal worden met een beschrijving van kinderhuwelijken in Nederland. Vervolgens wordt de gewijzigde wetgeving beschreven die kinderhuwelijken aan banden beoogt te leggen, wordt aangegeven welke belangen bij kinderhuwelijken in het geding kunnen zijn, om vervolgens na te gaan in hoeverre de nieuwe regelgeving bijdraagt aan bescherming van deze belangen.

\section{Nederland en kinderhuwelijken}

Kinderhuwelijken waarmee we in Nederland te maken krijgen, kunnen in een drietal categorieën worden onderscheiden: kinderhuwelijken die in Nederland via de officiële weg worden gesloten, kinderhuwelijken uit het buitenland, en de in Nederland tot stand gebrachte informele kinderhuwelijken.

\section{Officiële rechtsgeldige kinderhuwelijken in Nederland}

Tot 5 december 2015 stond de Nederlandse wet toe dat er in twee omstandigheden beneden de leeftijd van 18 jaar kon worden getrouwd: wanneer de vrouw zwanger was of reeds een kind ter wereld had gebracht en de huwelijkskandidaten de leeftijd van 16 jaar hadden bereikt (art. 1:31 lid 2 Burgerlijk Wetboek (BW) oud), en om gewichtige reden met ontheffing van de minister van Justitie (art. 1:31 lid 3 BW oud). Huwelijkskandidaten met een buitenlandse nationaliteit

8 Dettmeijer-Vermeulen, Esser \& Noteboom 2016, p. 43, 46-47.

9 Vragen (met antwoorden): Aanhangsel Kamerstukken II 2015/16, 2450; Aanhangsel Kamerstukken II 2015/16, 2454; Aanhangsel Kamerstukken II 2015/16, 639; Aanhangsel Kamerstukken II 2015/16, $2016 Z 03571$. 
konden in Nederland op grond van het internationaal privaatrecht (ipr) (art. 10:28 BW oud) op jongere leeftijd dan 18 jaar trouwen als dit was toegestaan volgens het recht van hun nationaliteit. Duidelijke cijfers van het aantal huwelijken die in Nederland via deze officiële weg werden gesloten, zijn er niet. Uit de parlementaire geschiedenis bij het wetsvoorstel tegen huwelijksdwang blijkt dat het zou gaan om rond de tien 16-jarige meisjes per jaar, rond de dertig 17-jarige meisjes per jaar en jaarlijks om één à twee 17-jarige jongens. Het gaat daarbij vrijwel steeds om gevallen van zwangerschap of situaties waarin er al een kind is geboren. Verzoeken om ontheffing van de minister werden de laatste jaren slechts enkele keren (één keer in 2011 en twee keer in 2012) toegewezen. In twee van deze gevallen betrof het een 15-jarig zwanger meisje en één keer een 16-jarig meisje dat een miskraam had gekregen. ${ }^{10}$ Er werden wel meer verzoeken om ontheffing ingediend, maar deze werden niet altijd toegewezen. Zo konden bijvoorbeeld de volgende motieven niet als gewichtige reden volstaan: de angst dat de vrouw naar het buitenland zou worden gestuurd en zou worden uitgehuwelijkt of vermoord, het gegeven dat de partners zich niet veilig voelden of dat het leven voor hen geen nut meer had, de omstandigheid dat de partners veel steun aan elkaar hadden, erg verliefd waren, dat een huwelijk na een moeilijke tijd het gevoel zou geven dichter bij elkaar te staan, financiële redenen, en ook het feit dat de verzoekers reeds een religieuze verbintenis waren aangegaan. ${ }^{11}$

Gegevens dat in Nederland burgerlijke huwelijken worden gesloten beneden de leeftijd van 18 jaar met toepassing van buitenlands recht, werden niet bijgehouden. ${ }^{12}$ In theorie kunnen ook op buitenlandse consulaire vertegenwoordigingen in Nederland kinderhuwelijken rechtsgeldig worden gesloten. Of dit daadwerkelijk gebeurt, is niet bekend.

\section{Kinderhuwelijken uit het buitenland}

Een tweede categorie kinderhuwelijken waarmee Nederland te maken krijgt, zijn kinderhuwelijken die in het buitenland worden gesloten en waarbij één of beide echtgenoten vervolgens naar Nederland komen of beogen te komen in het kader van asiel of via huwelijksmigratie. Het komt ook voor dat in het buitenland een huwelijk wordt gesloten met een in Nederland wonende partner, maar dat de buitenlandse echtgenoot niet naar Nederland komt, of zelfs dat de in Nederland wonende echtgenoot zich (op een gegeven moment) voegt bij de echtgenoot in het buitenland.

Er zijn ook in dit geval geen statistieken waarin deze kinderhuwelijken worden bijgehouden. In het verleden kwamen incidenteel gevallen aan het licht via rechtspraak waarin over de erkenning van het buitenlandse kinderhuwelijk moest wor-

10 Kamerstukken II 2012/13, 33488, 6 (Nota n.a.v. het Kamerverslag), p. 12, waarin de eerder gedane uitlating dat na 2007 geen ontheffingsverzoeken waren toegewezen (Kamerstukken II 2012/13, 33488, 3, p. 7 en 13), wordt gecorrigeerd.

11 Kamerstukken II 2012/13, 33488, 6, p. 12; nota naar aanleiding van het Kamerverslag 8 juli 2013, Kamerstukken II 2012/13, 33488, 6, p. 17.

12 Kamerstukken II 2012/13, 33488, 6, p. 20. 
den beslist. ${ }^{13}$ Dat ambtenaren bij gemeenten vaker over kinderhuwelijken moesten beslissen, kan worden afgeleid uit een publicatie van Gubbels, waarin hij stelt dat het aantal kinderhuwelijken in civiele procedures in schril contrast staat met het aantal huwelijksakten van kinderhuwelijken waarmee Nederlandse ambtenaren burgerzaken geconfronteerd worden. ${ }^{14}$ Van de 250 kinderhuwelijken die volgens het onderzoeksrapport Gewoon Getrouwd naar schatting in 2013 en 2014 per jaar voorkwamen en waarmee Nederland te maken kreeg, hadden er 80 betrekking op kinderhuwelijken binnen de asielopvang. Deze huwelijken werden buiten Nederland gesloten. Het rapport van de Nationaal Rapporteur Mensenhandel en Seksueel Geweld tegen Kinderen bevestigt een stijging van kinderhuwelijken binnen de asielopvang in $2015 .{ }^{15}$ Wat betreft de kinderhuwelijken buiten de asielopvang, hiervan werd een groot deel buiten Nederland gesloten. Bij deze kinderhuwelijken kan het gaan om huwelijken die in het land van huwelijksvoltrekking op rechtsgeldige wijze zijn gesloten, maar ook om huwelijken die niet rechtsgeldig, althans niet in overeenstemming met het ter plaatse geldende recht, werden gesloten.

De motieven voor kinderhuwelijken in het buitenland lopen uiteen. Vaak spelen geld en armoede (economische omstandigheden) een rol. ${ }^{16}$ Meisjes worden daarbij veeleer als object dan als subject gezien. Dwang en onvrijwilligheid bij het aangaan van de huwelijken zijn geen uitzondering. Dergelijke praktijken worden meestal door bestaande tradities, cultuur en mogelijk ook religieuze motieven getolereerd en in stand gehouden. ${ }^{17}$ De mogelijkheid om verblijf in Europa te krijgen vinden we eveneens in de literatuur terug als motief voor het aangaan van kinderhuwelijken in het buitenland. ${ }^{18}$ Ook werd aan huwelijken met een huwelijkskandidaat uit het land van herkomst wel de voorkeur gegeven omdat men dan trouwt met iemand die dezelfde culturele en religieuze achtergrond heeft. ${ }^{19}$ Jongeren zoeken deze huwelijkskandidaten echter steeds vaker in Nederland zelf. ${ }^{20}$ Andere motieven die in het onderzoek van Sterckx e.a. worden genoemd voor de keuze van een partner uit het buitenland zijn het op afstand houden van de schoonouders, ${ }^{21}$ dat laagopgeleide mannen nog wel eens hechten aan een Marokkaanse of Turkse opvoeding en aan een bepaalde traditionele rolverdeling

13 Bijv.: Rb. Almelo 20 februari 2002, NJ 2002/237, ECLI:NL:RBALM:2002:AE2244.

14 E. Gubbels, 'Inschrijving huwelijk in het buitenland met een minderjarige', Burgerzaken\&Recht 2002, p. 147.

15 Dettmeijer-Vermeulen, Esser \& Noteboom 2016, p. 43, 46-47. De organisatie Save the Children signaleerde in 2014 al dat het aantal kinderhuwelijken in vluchtelingenkampen in Jordanië als gevolg van de oorlog in Syrië sterk was toegenomen: Rapport Too Young to Wed. The growing problem of child marriage among Syrian girls in Jordan, The Save the Children Fund 2014.

16 Rapport Too Young to Wed 2014; Marrying too young; end child marriages, New York 2012.

17 Uitvoerig hierover: L. Sterckx e.a., Huwelijksmigratie in Nederland. Achtergronden en leefsituatie van huwelijksmigranten, Den Haag 2014, p. 126 e.v., met voorbeelden van kinderhuwelijken op p. 139-140.

18 E.K. Szepietowska, A. Dekker \& F. Özgümüs, De doos van Pandora. Huwelijksmigratie onder vluchtelingengroepen in Nederland, Amsterdam 2011, p. 20, en vergelijk ook p. 50 en 60.

19 Vgl. voor Marokkaanse en Turkse burgers: Sterckx e.a. 2014, p. 77-78.

20 Sterckx e.a. 2014, p.78-79 en 83-84, 85.

21 Sterckx e.a. 2014, p. 81. 
tussen de seksen, ${ }^{22}$ en voor vluchtelingen ook vrijheid. ${ }^{23}$ Voor de toename van kinderhuwelijken onder Syrische asielzoekers worden daarnaast ook veiligheid en bescherming tegen misbruik of verkrachting in de vluchtelingenkampen genoemd. ${ }^{24}$ Szepietowska e.a. wijzen op een zorgwekkende ontwikkeling bij nieuwkomers en meisjes in een asielzoekerscentrum (azc). Deze zouden 'met opzet [worden, SR] gekozen door Afghaanse en Somalische mannen, omdat deze meisjes "schoon", volgzaam en traditioneel zouden zijn. Bovendien is het voor deze mannen makkelijker een meisje dat nog in een AZC zit of pas net een status heeft uit te zoeken, dan op zoek te moeten in het herkomstland. ${ }^{25}$ Concretere informatie over deze situaties en over de vraag of het hier minderjarige meisjes betreft, ontbreekt nog.

\section{Informele kinderhuwelijken in Nederland}

Onder informele huwelijken worden huwelijken verstaan die worden gesloten op een wijze die afwijkt van de vorm welke is voorgeschreven in het land van huwelijkssluiting. Voor Nederland zijn dit dus huwelijken die niet bij de gemeente of op het consulaat worden gesloten.

Het is moeilijk om een volledig en betrouwbaar beeld te krijgen van alle informele kinderhuwelijken die in Nederland worden gesloten. Het zijn huwelijken die buiten de officiële weg tot stand worden gebracht en nergens worden geregistreerd. In verschillende (sociologische) onderzoeken wordt op het fenomeen van deze kinderhuwelijken gestuit. Het meest volledig is wellicht het recente onderzoek naar kinderhuwelijken en religieuze huwelijken in Nederland, zij het dat ook in dat onderzoek niet alle gemeenschappen specifiek zijn onderzocht. ${ }^{26}$ Een deel van de naar schatting circa 250 kinderhuwelijken waarmee we in 2013 en 2014 per jaar te maken kregen, had betrekking op kinderhuwelijken die in Nederland zelf waren gesloten. Het ging hier om informele huwelijken. Kinderhuwelijken lijken niet primair te koppelen te zijn aan religie, maar veeleer te maken te hebben met bestaande tradities of cultuur. ${ }^{27}$ Toch worden juist deze huwelijken nogal eens in verband met religie gebracht. Religieuze gemeenschappen in Nederland waarbinnen het bestaan van kinderhuwelijken werd gesignaleerd, zijn de christelijke (hoofdzakelijk (oosters) orthodoxe christenen en katholieken), islamitische, hindoestaanse en boeddhistische. ${ }^{28}$ Wat verder uit de literatuur en onderzoeksrapporten kan worden opgemaakt, is dat kinderhuwelijken mogelijk nog voorkomen 
bij de Roma en de Sinti, ${ }^{29}$ in de Afghaanse, ${ }^{30}$ Pakistaanse, ${ }^{31}$ Somalische ${ }^{32}$ en Surinaams-Hindoestaanse gemeenschap, ${ }^{33}$ en mogelijk in de Marokkaanse en Turkse gemeenschap. ${ }^{34}$ Soms worden de huwelijken door jongeren aangegaan om het hebben van een relatie te kunnen legitimeren ${ }^{35}$ of biedt het huwelijk de mogelijkheid om het ouderlijk huis te kunnen verlaten, ${ }^{36}$ een andere keer was het de familie die bijvoorbeeld een schending van de eer wilde voorkomen, de jongere in het gareel wilde houden' of eerder gemaakte huwelijksafspraken wilde nakomen. Daarbij kan sprake zijn van dwang. ${ }^{37}$ In andere dan religieuze kringen is het vaak een bestaande traditie die kan verklaren dat er nog kinderhuwelijken worden gesloten. Islamitische huwelijken met minderjarigen werden gesignaleerd binnen het Hofstadnetwerk. ${ }^{38}$ Groen en Kranenberg schrijven in hun uit 2006 daterende onderzoek naar radicale moslima's en het Hofstadnetwerk: 'Jonge moslims, soms zelfs nog minderjarig, huwen elkaar, zonder dat de ouders het weten, met behulp van radicale imams en (semi) geleerden. Zijn die niet voorhanden, dan sluiten ze het huwelijk gewoon onderling. Heel ingewikkeld is dat niet. De ceremonie duurt zo'n vijftien minuten en kan worden voltrokken in het bijzijn van twee moslimgetuigen. ${ }^{39}$ Vandaag de dag zijn er signalen die kunnen wijzen op informele islamitische huwelijken met minderjarigen binnen orthodoxe islamitische, salafistische ${ }^{40}$ en jihadistische kringen. ${ }^{41}$

\section{Wetgeving met betrekking tot kinderhuwelijken}

De wet

Met de nieuwe regeling heeft de wetgever de regels voor huwelijken beneden de 18 jaar aangescherpt. Artikel 1:31 BW werd gewijzigd, en ook de ipr-regels in titel 3 van Boek 10 BW over het huwelijk werden aangepast. De nieuwe regeling

29 Rutten e.a. 2015, p. 62.

30 FORUM, Migrantengemeenschappen over huwelijksdwang, Utrecht 2014, p. 11; Szepietowska, Dekker \& Özgümüs 2011, p. 19.

31 Zie bijv. het in noot 2 genoemde incident.

32 Rutten e.a. 2015, p. 62; FORUM 2014, p. 11 en 23.

33 Rutten e.a. 2015, p.62.

34 Rutten e.a. 2015, p.62.

35 A. Moors, Motieven om islamitische huwelijken aan te gaan, Utrecht: FORUM 2014, p. 11.

36 Moors 2014, p. 12.

37 Zie bijv. Szepietowska, Dekker \& Özgümüs 2011, p. 19.

38 J. Groen \& A. Kranenberg, Strijdsters van Allah. Radicale moslima's en het Hofstandnetwerk, Meulenhoff/de Volkskrant 2006, p. 51.

39 Groen \& Kranenberg 2006, p. 51.

40 S. Roex, J. van Stiphout \& J. Tillie, Salafisme in Nederland. Aard, omvang en dreiging, Amsterdam 2010, p. 149.

41 In de zaak voor Rechtbank Den Haag, uitspraak 1 december 2014, ECLI:NL:RBDHA:2014:14650 had het meisje bij de politie verklaard dat zij voor de islamitische wet was getrouwd, op een bankje bij het treinstation met een imam, en ook dat zij deed dit stiekem had gedaan omdat zij eerder al eens ruzie had gemaakt met haar ouders vanwege het feit dat zij met een Marokkaan wilde trouwen. In 2013 werd ook bericht over een Marokkaans 16-jarig meisje dat vanuit België naar Syrië vertrok en daar direct trouwde, zie o.m. www.volkskrant.nl/buitenland/belgische-bruid -als-beloning-voor-syrische-jihadstrijder a3484749/. 
komt erop neer dat voor huwelijken die in Nederland worden gesloten, een absolute minimum huwelijksleeftijd van 18 jaar is gaan gelden, waarop niet langer uitzonderingen worden toegestaan. In artikel 1:31 BW zijn de uitzonderingen voor zwangerschap (lid 2) en de ontheffingsmogelijkheid (lid 3) komen te vervallen. Een amendement om nog een uitzondering toe te laten en dus het huwelijk open te laten voor de minderjarige vrouw die zich vanwege de verzorging en opvoeding van haar kind meerderjarig heeft laten verklaren (art. 1:253ha BW), ${ }^{42}$ werd door de staatssecretaris niet overgenomen. ${ }^{43}$ In Boek 10 BW werd artikel 28 gewijzigd, als gevolg waarvan de huwelijksbevoegdheid van buitenlanders die in Nederland trouwen voortaan steeds zal worden beoordeeld naar Nederlands recht. Artikel 1:31 BW is daarmee ook steeds op buitenlanders van toepassing. Daarmee geldt deze regel voor iedereen die in Nederland wil trouwen. De regel die het trouwen op het consulaat mogelijk maakt (art. 10:30 BW) is niet gewijzigd. Huwelijkssluitingen op het consulaat blijven onderworpen aan het buitenlandse recht.

Voor huwelijken die in het buitenland worden gesloten, is de regeling nu zodanig dat huwelijken waarbij ten minste één van de huwelijkskandidaten bij de huwelijkssluiting de leeftijd van 18 jaar nog niet had bereikt, in Nederland niet meer als rechtsgeldig worden erkend. Bij de beoordeling van buitenlandse huwelijken wordt primair gekeken naar het huwelijksrecht van het land waar het huwelijk wordt gesloten. Het huwelijk moet in ieder geval volgens dat recht geldig zijn gesloten. Als het buitenlandse huwelijksrecht toestaat dat een huwelijk rechtsgeldig kan worden gesloten op 16-jarige leeftijd, is het huwelijk aldaar geldig. De wetgeving van de meeste staten kent tegenwoordig minimum huwelijksleeftijden. Deze leeftijden liggen in de regel niet beneden de 15 jaar. In de praktijk worden de wettelijk bepaalde leeftijden echter niet altijd gerespecteerd en worden huwelijken ook wel op jongere leeftijd gesloten in overeenstemming met bestaande gewoonten. Kinderhuwelijken komen wereldwijd nog veelvuldig voor. Bij de beoordeling in Nederland moet vervolgens worden gekeken of het buitenlandse huwelijk geen strijd oplevert met beginselen van de Nederlandse openbare orde. In artikel 10:32 BW is nu uitdrukkelijk bepaald dat een huwelijk kennelijk onverenigbaar is met de openbare orde ${ }^{44}$ indien een van de echtgenoten op het tijdstip van huwelijkssluiting niet de leeftijd van 18 jaar had bereikt (art. 10:32 sub c BW). Kennelijke onverenigbaarheid met de openbare orde wordt echter niet langer als vanzelfsprekend aangenomen indien de echtgenoten op het moment dat in Nederland om de erkenning van het buitenlandse huwelijk wordt gevraagd, de leeftijd van 18 jaar inmiddels hebben bereikt.

\section{Achtergronden en totstandkoming van de wet}

De aanpassing van de regelgeving omtrent kinderhuwelijken maakte onderdeel uit van een wet die tot doel had 'de huwelijksdwang verder te beteugelen en de erkenning van in het buitenland gesloten huwelijken te beperken tot hetgeen in 
overeenstemming is met het in Nederland meer algemeen ervaren karakter van het huwelijk'. ${ }^{45}$ Het huwen op jonge leeftijd wordt in verband gebracht met huwelijksdwang, met de redenering dat mensen op jonge leeftijd kwetsbaarder en meer beïnvloedbaar zijn, minder weerstand kunnen bieden aan de druk van de familie en niet altijd vrijwillig en zelfstandig kunnen beslissen.

De wetgever onderbouwt de aanpassing door te verwijzen naar de kwetsbare positie van de jongere en het feit dat deze een beschermde positie verliest omdat de jongere door het huwelijk meerderjarig wordt. Verder geeft de wetgever aan dat het niet ongebruikelijk is dat de minimum huwelijksleeftijd zich aanpast aan de realiteit van de dag; waar het in vroeger tijden nog vrij gebruikelijk was, met name voor meisjes, om jong te trouwen, is die gewoonte inmiddels in onbruik geraakt. ${ }^{46}$ In het verleden werd de huwelijksleeftijd meermaals aangepast. Het is pas sinds 1970 dat de huwelijksleeftijd voor meisjes en jongens gelijk is getrokken en voor beiden op 18 jaar werd gesteld. ${ }^{47}$ De wetgever wil thans huwelijkssluiting beneden de leeftijd van 18 jaar krachtig tegengaan en, zo stelt hij, na de verschillende belangen te hebben afgewogen, hierop geen uitzonderingen meer toestaan. ${ }^{48}$ Het voorstel om jonge moeders die zich meerderjarig hadden laten verklaren wel tot het huwelijk toe te laten als zij nog geen 18 jaar waren, heeft het niet gehaald omdat 'de regering het van groot belang vindt om in het kader van het tegengaan van huwelijksdwang vooral aandacht te besteden aan de extra kwetsbare groep van personen beneden de leeftijd van achttien jaar' ${ }^{\text {'49 }}$ en omdat met het openhouden van de mogelijkheid van huwelijkssluiting voor deze groep afbreuk zou worden gedaan aan de maatregelen die beogen huwelijksdwang tegen te gaan. ${ }^{50} \mathrm{Het}$ sluiten van een huwelijk bovenop een meerderjarigverklaring zou volgens de wetgever bovendien ook niet vanzelf een meerwaarde bieden. ${ }^{51}$ De wetgever koppelt derhalve aan de leeftijd van 18 jaar en niet aan de meerderjarigheid. ${ }^{52}$

Het schrappen van de uitzonderingen kreeg in de adviesronde die het oorspronkelijke wetsvoorstel heeft doorlopen aardig wat bijval van onder meer de Nederlandse Vereniging voor Burgerzaken en de Raad voor Strafrechtstoepassing en

45 Kamerstukken II 2012/13, 33488, 3, p. 1.

46 Kamerstukken II 2012/13, 33488, 3, p. 7, 8 en 10.

47 Kamerstukken II 2012/13, 33488, 3, p. 13.

48 Kamerstukken II 2014/15, 33488, C (memorie van antwoord), p. 17.

49 Kamerstukken II 2012/13, 33488, 3, p. 16. In art. 46 van het op 1 maart 2016 in werking getreden Verdrag ter voorkoming en bestrijding van geweld tegen vrouwen (Trb. 2012, 233) wordt het feit dat huwelijksdwang (art. 37) plaatsvindt tegenover een minderjarige, aangemerkt als verzwarende omstandigheid.

50 Kamerstukken II 2012/13, 33488, 3, p. 16.

51 Kamerstukken II 2012/13, 33488, 3, p. 16. In de uitgebrachte adviezen waren nog meer argumenten aangevoerd tegen het openlaten van het huwelijk voor meerderjarig verklaarde moeders, zoals de ongelijkheid tussen meisjes en jongens die art. 1:253ha BW impliceert (advies van de Raad voor Strafrechtstoepassing en Jeugdbescherming van 20 december 2011, Kamerstukken II 2012/13, 3), en de ongelijkheid die hiermee zou ontstaan tussen Nederlanders en buitenlanders (advies Staatscommissie IPR).

52 Dat sluit overigens niet direct aan bij de definitie van een kind zoals die is gegeven in het Kinderrechtenverdrag, waarin een kind in art. 1 wordt gedefinieerd als een mens jonger dan 18 jaar, tenzij volgens het op het kind van toepassing zijnde recht de meerderjarigheid eerder wordt bereikt. 
Jeugdbescherming. ${ }^{53}$ Twijfels werden echter geuit door de ChristenUnie en D66. De ChristenUnie vroeg zich af wat de aanleiding en noodzaak is om de uitzonderingen van artikel 1:31 BW te schrappen; huwelijken beneden de leeftijd van 18 jaar komen immers maar weinig voor en jonge ouders beogen met een dergelijk huwelijk enkel om bij zwangerschap het beste van de situatie te maken. Zij geeft in overweging om de uitzonderingen op de huwelijksleeftijd niet te schrappen, maar om hierin een extra waarborg in te bouwen opdat jongeren die willen trouwen een bewuste keuze kunnen maken en bekend zijn met de consequenties van een huwelijk. ${ }^{54}$ Vanuit D66 werd geopperd om een toetsing door de rechter in te voeren voor huwelijken beneden de 18 jaar. ${ }^{55}$ Ook het schrappen van de mogelijkheid voor een jonge moeder die meerderjarig is verklaard om te trouwen, stuitte bij de ChristenUnie-fractie op verzet; ruimte voor het hanteren van een hardheidsclausule in dit soort gevallen, is er dan immers niet meer. ${ }^{56}$ De fractie vraagt de regering ook hoe zij het belang van het tegengaan van dwanghuwelijken heeft afgewogen tegen het belang van jonge moeders om te kunnen trouwen. ${ }^{57}$ Daaraan kan worden toegevoegd dat binnen verschillende religieuze gemeenschappen de norm is dat er geen seksuele relatie kan worden onderhouden zonder getrouwd te zijn. Het huwelijk kan hier een oplossing bieden, met name waar jongeren relaties met elkaar willen aangaan. In zijn reactie merkt de staatssecretaris op dat het standpunt dat er in geval van zwangerschap getrouwd moet worden, niet meer van deze tijd is. Als je uitzonderingen beneden de 18 jaar toelaat, wordt de opvatting dat huwelijken beneden de 18 jaar in strijd zijn met fundamentele beginselen van onze rechtsorde minder overtuigend. Deze kunnen dan ook minder overtuigend worden ingeroepen tegen in het buitenland gesloten kinderhuwelijken. ${ }^{58}$ De bezwaren die de meerderjarig verklaarde moeder betreffen, worden door de staatssecretaris enigszins gerelativeerd; zij zal haar huwelijksplannen misschien even moeten uitstellen, maar in de praktijk gaat het doorgaans slechts om enkele maanden. Dit belang weegt niet op tegen het belang dat de samenleving heeft bij het tegengaan van huwelijksdwang, het afschaffen van kinderhuwelijken daaronder begrepen. ${ }^{59}$

\section{Waarom erkenning buitenlandse kinderhuwelijken aangescherpt?}

Met de concretisering van een aantal gronden waarin de openbare orde moet worden ingeroepen, heeft de wetgever rechtszekerheid willen bieden en de wetstoepasser behulpzaam willen zijn bij de beoordeling van de openbare-orde-exceptie. ${ }^{60}$

53 Bijlagen bij Kamerstukken II 2012/13, 33488, 3 (adviezen).

54 Tweede Kamerverslag 13 februari 2013, Kamerstukken II 2012/13, 33488, 5, p. 9: bijv. door een extra toets door de bijzondere ambtenaar van de burgerlijke stand of door ook hier te vereisen dat alleen mag worden getrouwd indien de minister ontheffing verleent.

55 Kamerlid Schouw (D66) tijdens de Kamerbehandeling op 20 maart 2014, Kamerstukken II 2013/14, 33488, 65, p. 5.

56 Segers (ChristenUnie) tijdens de Kamerbehandeling op 20 maart 2014, Kamerstukken II 2013/14, 33488, 65, p. 4.

57 Behandeling in de Eerste Kamer, Kamerstukken I 2014/15, 33488, B, p. 8.

58 Kamerbehandeling op 20 maart 2014, Kamerstukken II 2013/14, 33488, 65, p. 10.

59 Memorie van antwoord, Kamerstukken I 2014/15, 33488, C, p. 15.

60 Kamerstukken II 2012/13, 33488, 3 (memorie van toelichting), p. 11. 
Eveneens kan met deze regel worden voorkomen dat huwelijkskandidaten ervoor kiezen om naar het buitenland te gaan en daar een huwelijk beneden de leeftijd van 18 jaar te sluiten. Het belang om bescherming te bieden tegen huwelijksdwang verlangt het hanteren van een duidelijke norm waaraan niet getornd kan worden. ${ }^{61}$ De wetgever heeft hierdoor niet alleen de door hem beoogde duidelijkheid gegeven, maar ook een moreel oordeel geveld over de huwelijksleeftijd; in geen enkele situatie kan een huwelijk beneden de leeftijd van 18 jaar worden gerechtvaardigd.

Een direct en concreet antwoord op de vraag waarom álle buitenlandse huwelijken beneden de leeftijd van 18 jaar per definitie strijdig zijn met de fundamentele beginselen van onze rechtsorde, komt er niet. Ook huwelijken die in het buitenland rechtsgeldig zijn gesloten, en huwelijken waar zwangerschap de aanleiding was voor het huwelijk en waar het huwelijk mogelijk is gesloten met goedkeuring van de buitenlandse rechter, worden voortaan strijdig geacht met de Nederlandse openbare orde en dientengevolge niet erkend zolang de betrokkenen niet 18 jaar zijn. Dat in Nederland zelf tot voor kort nog uitzonderingen op de regel werden toegelaten, met name in geval van zwangerschap, dat op dit beleid geen noemenswaardige kritiek bestond, dat meerdere Europese landen een lagere huwelijksleeftijd hanteren of uitzonderingen kennen in geval van zwangerschap, is voor de wetgever niet overtuigend geweest. In plaats van te motiveren waarom álle huwelijken beneden de 18 onverenigbaar zijn met de openbare orde, lijkt het doel van de regeling, te weten het tegengaan van huwelijksdwang, te domineren. Daarvoor is de openbare-orde-exceptie eigenlijk niet bedoeld, en daardoor wordt de internationaal privaatrechtelijke openbare orde feitelijk oneigenlijk opgerekt. ${ }^{62}$

Enigszins merkwaardig is wellicht dat de wetgever deze strenge lijn niet doortrekt als de gehuwden inmiddels 18 jaar zijn geworden. Dan geldt de imperatieve weigeringsgrond van de openbare orde immers niet meer. Volgens de wetgever hoeft er geen reden meer te zijn om erkenning aan het huwelijk te onthouden als de echtgenoten de leeftijdsgrens van 18 jaar zijn gepasseerd. ${ }^{63}$ Ook Gubbels meent dat de weerstand die tegen de erkenning van kinderhuwelijken bestaat, er niet meer zal zijn zodra de vrouw, of althans de echtgenoten, niet meer die jonge leeftijd heeft (hebben). ${ }^{64}$ Dat is misschien wel erg algemeen gesteld. Het betekent dat huwelijken beneden de leeftijd van 18 jaar in het buitenland kunnen worden gesloten en vervolgens in Nederland rechtsgeldig worden als de huwelijkskandidaten wachten met het vragen van erkenning ervan tot zij beiden 18 jaar zijn. Hoe kun je nu heel absoluut huwelijken beneden de 18 jaar in alle gevallen en ongeacht de omstandigheden strijdig bevinden met de fundamentele beginselen van openbare orde, maar 'even later' toch bereid zijn ze te erkennen? Je geeft dan als land toch minstens een wat halfslachtig signaal af, en het is ook geen sterke

61 Nota n.a.v. het Kamerverslag van 8 juli 2013, Kamerstukken II 2012/13, 33488, 6, p. 19.

62 Aldus ook het advies van de Raad voor Strafrechtstoepassing en Jeugdbescherming; advies Staatscommissie IPR.

63 Kamerstukken II 2012/13, 33488, 3, p. 14.

64 Gubbels 2002, p. 149 en 151. 
stimulans om buitenlandse kinderhuwelijken daadwerkelijk structureel te ontmoedigen.

Hoewel de bewoordingen van artikel 10:32 BW de erkenning van kinderhuwelijken algemeen mogelijk lijken te maken zodra de echtgenoten de leeftijd van 18 jaar hebben bereikt, lijkt uit de parlementaire geschiedenis te volgen dat dit alleen geldt als de Nederlandse rechtsorde niet bij de huwelijkssluiting was betrokken. In de memorie van toelichting lezen we immers: 'Als evenwel de Nederlandse rechtsorde niet betrokken was op het moment dat een minderjarige een huwelijk sloot en de echtgenoten op het moment dat erkenning van het huwelijk gevraagd wordt de leeftijdsgrens van achttien jaar gepasseerd zijn, is er geen reden erkenning aan het huwelijk te onthouden.' ${ }^{65}$ Als dit ook impliceert dat bij de beoordeling of de exceptie van de openbare orde zal worden ingeroepen meer in ruime zin rekening kan worden gehouden met de omstandigheden van het geval, dan ben ik daar een groot voorstander van. De betrokkenheid van de Nederlandse rechtsorde bij het huwelijk kan daarbij dan een factor van betekenis zijn, maar hoeft misschien niet per definitie steeds bepalend te zijn. Nog steeds kan het huwelijk dan strijdig met de openbare orde worden bevonden, ook al zijn de echtgenoten inmiddels beiden meerderjarig, bijvoorbeeld omdat op heel jonge leeftijd is getrouwd en het meisje is geëxploiteerd voor oneigenlijke doelen. Anderzijds is er dan ook ruimte om in gevallen waarin beide echtgenoten vrede hebben met het huwelijk, er inmiddels mogelijk een gezin en gezinsleven is ontstaan, dat overigens ook behoort te worden beschermd op grond van artikel 8 van het Europees Verdrag voor de rechten van de mens, om dan de leeftijd waarop het huwelijk tot stand kwam niet langer tegen te werpen.

Voor de situaties waarin een huwelijk erkend kan worden zodra de leeftijd van 18 jaar is bereikt, laat de wet nog een paar zaken ongeregeld. Ten eerste is niet duidelijk vanaf welk moment het huwelijk dan moet worden erkend: is dit de datum van huwelijkssluiting en heeft de erkenning dus terugwerkende kracht (waarmee feitelijk het kinderhuwelijk wordt erkend), of geldt het moment dat de echtgenoten beiden 18 jaar werden (het moment waarop het huwelijk niet langer strijdig wordt geacht met de openbare orde), of is het huwelijk geldig vanaf het moment van de erkenning? En als de erkenning geen terugwerkende kracht heeft (vermoedelijk de meest aannemelijke optie), wat is dan het beleid ten aanzien van de gevolgen die het huwelijk heeft gehad vóór het moment van erkenning? Wat gebeurt er bijvoorbeeld met de kinderen die voordien, maar tijdens het huwelijk, waren geboren? Een tweede punt waaraan niet expliciet aandacht wordt gegeven, is of de erkenning die vanaf 18 jaar kan plaatsvinden van rechtswege kan intreden. Stel dat aan het kinderhuwelijk aanvankelijk erkenning was onthouden, wordt dit dan op een gegeven moment automatisch wel een rechtsgeldig huwelijk, ook zonder dat men dit in de gaten hoeft te hebben en ook als een van de echtgenoten dit eigenlijk niet wil? Of moet uitdrukkelijk om erkenning worden gevraagd? En staat het echtgenoten of een van de echtgenoten vrij de erkenning in te roepen op een moment dat dit haar, hem of hen goed uitkomt? Het lijken 
technische vragen, maar deze zouden praktisch wel eens van grote betekenis kunnen zijn.

Op 22 september wordt vastgesteld dat de openbare behandeling van het wetsvoorstel voldoende is voorbereid. ${ }^{66}$ Nog geen week later verschijnen in de media berichten over kindbruiden die asiel aanvragen in Nederland. Het wetsvoorstel dat inmiddels uitvoerig was voorbereid, werd gezien als een middel dat deze kinderhuwelijken zou kunnen beteugelen. Er moest dus haast met dit wetsvoorstel worden gemaakt. In plaats van de oorspronkelijk beoogde finale behandeling in de Eerste Kamer, werd het wetsvoorstel op 6 oktober 2015 zonder beraadslaging en zonder stemming als hamerstuk aangenomen.

\section{Belangen bij het tegengaan van kinderhuwelijken}

Bestrijding van kinderhuwelijken staat al lang op de internationale agenda. Tot voor kort ging de aandacht van de internationale gemeenschap hierbij steeds uit naar kinderhuwelijken in niet-westerse landen (sub-Sahara Afrika, Arabische landen, Oost- en Zuidoost-Azië, Latijns-Amerika enz.). ${ }^{67}$ Kinderhuwelijken treffen vooral meisjes. Internationaal worden juridische instrumenten ontwikkeld waarin wordt gepoogd bescherming te bieden tegen deze kinderhuwelijken. De Raad van Europa vaardigde in 2005 een resolutie uit tegen gedwongen huwelijken en kinderhuwelijken. ${ }^{68}$ Er is een VN-verdrag dat verdragsstaten verplicht om een minimum huwelijksleeftijd in hun wetgeving op te nemen. ${ }^{69}$ De Algemene Vergadering van de $\mathrm{VN}$ en de Internationale Commissie voor de Burgerlijke Stand bevalen in de jaren zestig en zeventig aan een minimum huwelijksleeftijd van 15 jaar aan te houden met het argument dat een kind immers een stadium moet hebben bereikt van voldoende fysieke en intellectuele rijpheid. ${ }^{70}$ De Raad van Europa ging in 2005 nog uit van een minimum huwelijksleeftijd van 18 jaar en adviseerde om de erkenning van buitenlandse kinderhuwelijken te weigeren. ${ }^{71}$ Vorig jaar heeft het Europese Hof voor de Rechten van de Mens zich in het kader van een asielverzoek moeten uitlaten over de vraag naar de erkenning van een kinderhuwelijk dat

66 Eindverslag van de Vaste Commissie voor Veiligheid en Justitie, Kamerstukken I 2015/16, 33488, D.

67 Zie bijv.: Marrying too young; end child marriages 2012.

68 Council of Europe: Parliamentary Assembly, Resolution 1468 (2005) on Forced Marriages and Child Marriages, 5 oktober 2005, 1468 (2005), te raadplegen via: www.refworld.org/docid/ 43f5d5184.html.

69 Verdrag van New York inzake de huwelijkstoestemming, de minimumleeftijd waarop een huwelijk mag worden aangegaan en de registratie van huwelijken, New York 1962, Trb. 1964, nr. 55, artikel 2.

70 VN: Recommendation on Consent to Marriage, Minimum Age for Marriage and Registration of Marriages, General Assembly Resolution 2018 (XX), 1 november 1965, Principle II. Commissie Burgerlijke Stand: Aanbeveling 2, Wenen 8 september 1976, zie: http://ciec1.org/ ListeRecommandations.html.

71 Council of Europe: Parliamentary Assembly, Resolution 1468 (2005) on Forced Marriages and Child Marriages, 5 oktober 2005, 1468 (2005), te raadplegen via: www.refworld.org/docid/ 43f5d5184.html, artikel 12, 14.2.1 en 14.2.4. 
in Afghanistan was gesloten terwijl de bruid de leeftijd van 14 jaar had. ${ }^{72}$ Het Europese Hof oordeelde dat Zwitserland niet verplicht was dit huwelijk te erkennen, en benadrukte daarbij het belang om het kind te beschermen.

De minimumleeftijd dient ook een doel; bij kinderhuwelijken kunnen immers grote belangen, fundamentele rechten en vrijheden van het kind in het geding zijn. Kinderhuwelijken vormen een bedreiging voor de fysieke, psychische en emotionele ontwikkeling van het kind. In het VN-rapport uit 2012 wordt dit omschreven als dat een kinderhuwelijk 'effectively brings a girl's childhood and adolescence to a premature and unnatural end by imposing adult roles and responsibilities before she is physically, psychologically and emotionally prepared' ${ }^{73}$ Het kan leiden tot sociale isolatie van het kind, het afbreken van scholing, ongewenste of gedwongen seksuele betrekkingen, vergrote risico's op geslachtsziekte, meisjes kunnen worden geëxploiteerd voor arbeid of prostitutie, kunnen zwanger raken, met bijbehorende gezondheidsrisico's en fysieke gevolgen, en kinderhuwelijken nemen meisjes de mogelijkheid af om zich te ontwikkelen tot gezonde, productieve en emancipatoire burgers. ${ }^{74}$

Het is pas sinds vrij kort dat West-Europese landen, waaronder Nederland, zich realiseren dat kinderhuwelijken ook hun probleem zijn. Actuele maatschappelijke ontwikkelingen legden nieuwe kwetsbaarheden bij huwelijken van met name jonge meisjes bloot. Ten eerste worden kinderhuwelijken in verband gebracht met gedwongen huwelijken. Kinderen zijn beïnvloedbaar voor sociale en emotionele druk uit hun omgeving, overzien hun mogelijkheden vaak nog niet en kunnen hierdoor gedwongen of zonder informed consent in een huwelijk betrokken raken. Gedwongen huwelijken vinden zowel plaats in Nederland als in de landen van herkomst met een in Nederland wonende huwelijkspartner. Een tweede zorg is er voor informele huwelijken die in Nederland worden gesloten onder jongeren binnen radicale islamitische kringen, ${ }^{75}$ waardoor met name meisjes zich binden aan radicaliserings- of terroristische groeperingen. ${ }^{76}$ Ten slotte krijgen Europese landen te maken met kindbruiden onder asielzoekers, waarbij het risico aanwezig is dat zij het slachtoffer zijn van kinderhandel en er een gevaar op de loer kan liggen dat zij worden geëxploiteerd voor oneigenlijke doeleinden.

Daar staat tegenover dat kinderhuwelijken in Nederland niet altijd problematisch hoeven te zijn en niet in alle gevallen per definitie tot grove mensenrechtenschendingen hoeven te leiden. Jongeren willen in Nederland soms zelf beneden de leeftijd van 18 jaar trouwen omdat het huwelijk een manier is om een relatie te kunnen hebben met de partner van de eigen keuze. Vaak gaat het daarbij, waar het minderjarigen betreft, om leeftijden van 15, 16 en 17 jaar. Deze huwelijken kunnen vrijwillig en weloverwogen worden aangegaan. Ook wanneer een meisje

EHRM 8 december 2015, 60119/12 (Z.H. en R.H./Zwitserland).

Rutten e.a. 2015, p. 11.

O.m. Marrying too you; end child marriages 2012; Too Young to Wed 2014; Dettmeijer-Vermeulen, Esser \& Noteboom 2016, p. 45-49.

En mogelijk, wanneer wordt afgereisd naar het buitenland om bij te dragen aan de jihadistische strijd, tijdens deze reis in het buitenland.

Rapport van de Nationaal Coördinator Terrorismebestrijding, Informele islamitische huwelijken. Het verschijnsel en de veiligheidsrisico's, Den Haag 2006. 
zwanger raakt, kan vanuit religieus oogpunt een huwelijk wenselijk geacht worden. Voor Nederlandse ingezetenen geldt bovendien dat het belang dat aan scholing wordt toegekend, de beschikbaarheid van voorbehoedmiddelen en een goede gezondheidszorg de kans verminderen dat meisjes vroegtijdig zwanger raken of ernstige fysieke gevolgen oplopen, en verminderen de noodzaak om te trouwen. Ook aandacht voor goede informatievoorziening, empowerment van jonge meisjes, een framewerk van controle en gereguleerde jeugdzorg en jeugdbescherming kunnen bijdragen aan bescherming van bepaalde belangen die bij kinderhuwelijken gevaar dreigen te lopen.

\section{Daadwerkelijke betekenis van de nieuwe wet}

In deze paragraaf zal worden onderzocht of en op welke wijze de nieuwe wetgeving kan bijdragen aan het verminderen van kinderhuwelijken en het oplossen van de met deze huwelijken gepaard gaande mogelijke problemen. Daarnaast wordt bekeken of met de wetswijziging niet andere belangen in het geding dreigen te komen. Daarbij wordt onderscheid gemaakt tussen de gevolgen die de wetswijziging heeft voor de kinderhuwelijken die in Nederland wel of niet nog kunnen worden gesloten enerzijds, en de gevolgen voor kinderhuwelijken die buiten Nederland worden aangegaan, maar waarmee Nederland wel te maken krijgt.

\section{Gevolgen van het niet toestaan van kinderhuwelijken in Nederland}

Met de inwerkingtreding van de nieuwe wet kunnen in Nederland officieel geen huwelijken beneden de leeftijd van 18 jaar meer worden gesloten. De grootste verandering die ook praktische betekenis heeft, is dat de gevallen waarin de wetgever voorheen nog een uitzondering voor huwelijken beneden de 18 jaar toeliet, nu zijn verboden. De wetswijziging treft daarom vooral gevallen waarin het meisje zwanger is terwijl een huwelijk wenselijk wordt geacht. Vroeger was het gebruikelijk dat men bij zwangerschap ging trouwen. Tegenwoordig is dat in Nederland geen gemeengoed meer, maar in religieuze kringen is dit meestal nog wel van groot belang. Met het huwelijk kunnen het hebben van een seksuele relatie en de geboorte van een kind worden gelegitimeerd. Daarnaast wordt een huwelijk nodig gevonden om als partners met elkaar te kunnen gaan samenwonen. Zonder huwelijk behoort men niet te 'hokken', en als de ouders niet mogen samenwonen, kunnen zij ook niet samen de opvoeding van het kind oppakken. ${ }^{77}$ De nieuwe regel treft daarmee vermoedelijk het hardst de meisjes die zwanger raken en die, vaak om religieuze redenen, willen trouwen of verondersteld worden te trouwen. In het laatste geval, waarbij sprake kan zijn van druk van de familie of de omgeving, is het denkbaar dat dit aanleiding biedt tot een huwelijk in de informele sfeer, een huwelijk in het buitenland of een huwelijk op het consulaat. ${ }^{78}$ Dat zou een indirect negatief effect van de wetswijziging kunnen worden.

78 Als het al niet tot ernstigere reacties leidt, als bijvoorbeeld de eer van de familie op het spel staat. 
De gewijzigde huwelijkswetgeving is alleen gericht op de burgerlijke huwelijkssluiting. Zij treft niet de huwelijken die buiten de formele rechtsorde worden gesloten, omdat deze rechtens geen geldigheid kunnen hebben. Die huwelijken kunnen daarom gesloten blijven worden. Ook al zou het hier gaan om kinderhuwelijken, huwelijken die onder dwang tot stand worden gebracht of worden gesloten omwille van het behoren tot een radicale groepering, de nieuwe huwelijkswetgeving die zich enkel richt op formele huwelijken en niet op informele huwelijken biedt geen bescherming tegen het aangaan hiervan. ${ }^{79}$ Het zijn ándere wetsartikelen die deze informele huwelijken beogen tegen te gaan, te weten de regels die gebieden dat aan een religieus huwelijk een burgerlijk huwelijk vooraf dient te gaan (art. 1:68 BW en art. 449 Wetboek van Strafrecht (Sr)) en ook verschillende andere strafbepalingen. ${ }^{80}$

\section{Gevolgen van het niet erkennen van buitenlandse kinderhuwelijken}

De wetgever kan niet verbieden dat burgers kiezen voor een huwelijkssluiting in het buitenland of op een consulaat. De wetgever probeert echter wel tegen te gaan dat dergelijke buitenlandse huwelijken op jonge leeftijd worden gesloten. Dat doet hij thans via een aanscherping van de regels voor erkenning van buitenlandse huwelijken. De wetgever wil niet alleen buitenlandse kinderhuwelijken zo veel mogelijk voorkomen, maar alle huwelijken die in het buitenland onder dwang tot stand worden gebracht. De gedachte daarbij is dat wanneer men weet dat het huwelijk in Nederland niet als rechtsgeldig zal worden erkend, men eerder van het sluiten van een dergelijk huwelijk zal afzien. Eerder is uiteengezet dat mensen heel uiteenlopende motieven kunnen hebben voor een huwelijk in het buitenland en meer specifiek voor het aangaan van een kinderhuwelijk in het buitenland. Te verwachten is dat een afname van deze huwelijken alleen aan de orde is daar waar men voorheen de kinderhuwelijken aanging met het oog op een spoedig verblijf in Nederland. Voor alle overige situaties is nog te bezien of de Nederlandse wetgeving enig effect zal hebben op migratiehuwelijken. De toekomst zal dit moeten uitwijzen.

Uit onderzoek is gebleken dat de meeste kinderhuwelijken waarmee Nederland te maken krijgt, huwelijken zijn die in het buitenland worden gesloten. De gevolgen van de wijziging van de erkenningsregel zouden dan ook van grotere betekenis kunnen zijn dan de wijzigingen in Boek 1 BW en in de conflictregel voor huwelijken in Boek 10 BW. Buitenlandse huwelijken die werden gesloten beneden de leeftijd van 18 jaar, kunnen niet langer worden erkend in Nederland. Tot

79 Vergelijk Zweden, waar maatregelen tegen informele huwelijken wel wettelijk werden geaccepteerd. Zie G. Lambertz, 'Child Marriages and the Law - with Special Reference to Swedish Developments', in: M. Jänterä-Jareborg (red.), The Child’s Interests in Conflict, Cambridge/Antwerpen/ Portland 2016, p. 107.

80 Afhankelijk van de concrete omstandigheden is hierbij zoal te denken aan mensenhandel (art. 273 Sr), onttrekking van de minderjarige aan het ouderlijk gezag (art. 279 en 280 Sr), schaking (art. 281 Sr), wederrechtelijke vrijheidsberoving (art. 282 en 282a Sr), dwang (art. 284 Sr), ontucht (art. $243 \mathrm{t} / \mathrm{m} \mathrm{248f} \mathrm{Sr),} \mathrm{en} \mathrm{verzwijging} \mathrm{van} \mathrm{het} \mathrm{bestaan} \mathrm{van} \mathrm{een} \mathrm{huwelijksbeletsel} \mathrm{(art.}$ 238 Sr). De ambtenaar van de burgerlijke stand die op de hoogte is van het bestaan van een huwelijksbeletsel, pleegt een strafbaar feit (art. 379 lid 2 Sr). 
5 december 2015 was erkenning wel mogelijk; per individueel geval kon worden beoordeeld of de openbare orde zich tegen erkenning verzette. In de praktijk vond erkenning ook plaats, zeker als de betrokkenen bij huwelijkssluiting 15 jaar of ouder waren en de Nederlandse rechtsorde op dat moment niet bij het huwelijk was betrokken; ${ }^{81}$ de internationaal aanvaardbare minimumnorm werd doorgaans verondersteld op de leeftijd van 15 jaar te liggen. Bij een dergelijk erkenningsbeleid konden de in landen van herkomst bestaande praktijken waarbij meisjes op jonge leeftijd het huwelijk in gingen, in Nederland worden getolereerd. Dat kan nu niet langer meer. ${ }^{82}$ Althans, zolang de vrouw en man bij het verzoek om erkenning van hun huwelijk niet beiden de leeftijd van 18 jaar hebben bereikt. De eerste uitspraken die naar buiten komen, laten zien dat de Nederlandse rechter kritisch staat tegenover de erkenning van kinderhuwelijken. Zo moest het Gerechtshof Amsterdam oordelen over de erkenning van een in 1994 in Marokko gesloten huwelijk waarbij het meisje ten tijde van de huwelijkssluiting nog minderjarig was. De vrouw had aangegeven dat zij destijds niet vrijelijk haar toestemming voor het huwelijk had gegeven. Het hof overwoog: 'Naar het oordeel van het hof behoort, zeker bij een huwelijk van een minderjarige, boven twijfel verheven te zijn dat de instemming met de voltrekking uit vrije wil is gegeven.' Het verlangde van de man te bewijzen dat de vrouw wél vrijelijk haar toestemming had gegeven. $\mathrm{Nu}$ de man hierin niet was geslaagd, oordeelde het hof dat het huwelijk, ondanks dat dit in Marokko een rechtsgeldig huwelijk was, in Nederland wegens strijd met de openbare orde niet kon worden erkend..$^{83}$

Wanneer een buitenlands kinderhuwelijk in Nederland niet wordt erkend, wordt er juridisch gezien geen huwelijk aangenomen en worden de echtgenoten juridisch niet als echtgenoten beschouwd. Dat verondersteld ontbreken van een huwelijk werkt door in andere zaken en verhoudingen. Mocht er uit het huwelijk een kind worden geboren, dan staat het vaderschap van de man niet vanzelf vast. Is het kind in het buitenland geboren, dan hangt het ervan af of bij de erkenning van het vaderschap de niet-erkenning van het huwelijk wordt tegengeworpen. Wordt het kind in Nederland geboren, dan zal de vader het kind uitdrukkelijk moeten erkennen om als vader te worden aangemerkt. Gezag krijgt de vader ook niet van rechtswege; daarvoor heeft hij de medewerking van de moeder nodig. ${ }^{84}$ Als het buitenlandse huwelijk niet wordt erkend, wordt in Nederland aangenomen dat het meisje ondanks haar huwelijk niet meerderjarig is geworden en dus

81 Gubbels 2002, p. 149-150.

82 De wetgever heeft geen overgangsrechtelijke bepaling voor de aangepaste erkenningsregel opgenomen. Onduidelijk is daarom of de gewijzigde erkenningsregel ook kan worden toegepast op buitenlandse huwelijken die vóór 5 december 2015 werden gesloten. Rechtbank Limburg heeft dit, vooruitlopend op de wetswijziging, wel gedaan, Rb. Limburg 11 november 2015, ECLI:NL:RBLIM:2015:11084. Uit het sinds 5 december 2015 afwijzen van MVV-aanvragen in het kader van nareis en reguliere gezinshereniging als ten minste een van de (huwelijks)partners jonger is dan 18 jaar (zie brief van de staatssecretaris, Kamerstukken II 2015/16, 19637, 2146, p. 2) volgt impliciet dat de vreemdelingenautoriteiten ervan uitgaan dat de nieuwe wet ook kan worden toegepast op voor die tijd gesloten kinderhuwelijken.

83 Gerechtshof Amsterdam 19 april 2016, ECLUI:NL:GHAMS:2016:1507.

84 Art. 1:252 BW. 
nog minderjarig is. ${ }^{85}$ Is het meisje nog minderjarig en is zij zonder haar ouders ${ }^{86}$ naar Nederland gekomen, dan zal in Nederland in het gezag moeten worden voorzien; Nidos vraagt in dit geval de voogdij voor het kind aan. Jeugdzorgautoriteiten zullen zich (kunnen) gaan ontfermen over de belangen van het meisje. Het meisje kan aan haar huwelijkse staat geen verblijfsrecht ontlenen. ${ }^{87}$ Een verblijf in het kader van gezinshereniging is niet meer mogelijk of wordt bemoeilijkt. Mocht het huwelijk in Nederland daarentegen wél worden erkend, dan was het meisje gehuwd en was er niet langer ruimte voor de bemoeienis van jeugdzorgautoriteiten. De rapporteur mensenhandel wijst erop dat het feit dat het buitenlandse kinderhuwelijk niet wordt erkend, niet voorkomt dat de echtgenoten zelf en de gemeenschap het huwelijk wél als gesloten aanmerken. De huwelijken blijven in de informele sfeer van kracht, waarbij een risico bestaat dat de meisjes uit beeld verdwijnen uit angst dat zij van hun partner worden gescheiden. ${ }^{88}$

Wil Nederland voorkomen dat kinderhuwelijken met het oog op huwelijksmigratie worden gesloten, dan zal dit effectiever kunnen geschieden door een streng migratierecht op dit punt dan door een streng erkenningsbeleid van huwelijken in het internationaal privaatrecht. Een streng erkenningsbeleid kan mogelijk weer wél een rol spelen bij de bescherming van kindbruidjes tegen exploitatie door hun echtgenoot, aangezien een dergelijk huwelijk strijdig is met de openbare orde. Zolang het huwelijk niet wordt erkend en het meisje minderjarig is, ligt er een taak bij jeugdzorg om opvang en gezag voor het meisje te regelen en wordt de zeggenschap van de 'echtgenoot' over het meisje niet erkend. Zodra het meisje 18 jaar wordt, kan in theorie het huwelijk echter wel weer worden erkend, ook al was het gesloten op een moment dat het meisje nog jonger was. Erkenning zou ook dan alsnog kunnen worden geweigerd bij strijd met de openbare orde. Mogelijk dat op dat moment meer zicht is op de omstandigheden waaronder het huwelijk was aangegaan, en of het meisje het huwelijk vrijwillig was aangegaan, ${ }^{89}$ en dus duidelijker is of er reden is om de openbare orde alsnog in te roepen tegen de erkenning van het huwelijk. ECLI:NL:RBLIM:2015:11084. Helemaal vanzelfsprekend is dit overigens niet; het internationaal privaatrecht is op dit punt lastig.

86 Althans zonder degenen die gezag over haar hebben.

87 Dat was overigens sowieso niet aan de orde omdat Nederland bij huwelijksmigratie een minimumleeftijd van 21 jaar hanteert (art. 3.14 Vreemdelingenbesluit). Voor de nareizende echtgenoot geldt de leeftijd van 18 jaar.

88 Dettmeijer-Vermeulen, Esser \& Noteboom 2016, p. 50-51.

89 Ondanks de toegenomen kennis over huwelijksdwang en getroffen maatregelen, zoals voorlichting die door diverse instanties en organisaties wordt gegeven (ook via websites), en een circulaire van de staatssecretaris van Veiligheid en Justitie en de minister van Binnenlandse Zaken en Koninkrijksrelaties van 18 december 2013, ingangsdatum 6 januari 2014, gericht aan de colleges van B\&W en ambtenaren van de burgerlijke stand (www.nvvb.nl/media/nvvbfiles/system/files/ Circulaire\%20huwelijkse\%20dwang.pdf) zal het vaak nog moeilijk vast te stellen zijn dat een huwelijk onder dwang tot stand is gekomen. 


\section{Conclusie}

Kinderhuwelijken zijn in korte tijd geworden tot een beleidsonderwerp dat op veel belangstelling mag rekenen. Daarbij staat de zorg voor de belangen van het kind voorop. Kinderhuwelijken zijn niet in algemene zin te koppelen aan religie, maar vaak aan economische of pragmatische omstandigheden, mogelijk gepaard gaande met culturele tradities. Wel lijkt nog een zekere zorg aanwezig dat (in bepaalde kringen) religieuze autoriteiten in Nederland hun medewerking verlenen aan huwelijken van minderjarigen. Wat de nieuwe wet betreft kan concluderend worden gesteld dat deze, waar het de aanscherpingen van de huwelijksleeftijd betreft, in zoverre kan leiden tot een afname van kinderhuwelijken, dat in Nederland zelf officieel geen kinderhuwelijken meer gesloten kunnen worden, met name ook niet in geval van zwangerschap. Dat zou in religieuze gemeenschappen wel eens harder kunnen aankomen dan bij niet-gelovigen, aangezien religies er nogal eens van uitgaan dat verwekking van kinderen binnen een huwelijk dient plaats te vinden. In theorie zou dit kunnen betekenen dat mogelijk eerder uitgeweken wordt naar huwelijken in het buitenland of huwelijkssluiting in de informele sfeer. Het effect van de wet op buitenlandse kinderhuwelijken is minder goed te voorspellen, maar zal zich mogelijk beperken tot een afname van kinderhuwelijken daar waar deze voorheen werden gesloten met het oog op een spoedig verblijf in Nederland. In zoverre biedt de wetgeving ook bescherming tegen mogelijke gevallen van huwelijksdwang. Het ligt voor de hand dat met een Nederlandse wet de problematiek van kinderhuwelijken in het buitenland niet kan worden opgelost. Nederland zendt hiermee echter wel een signaal uit naar het buitenland, namelijk dat dergelijke huwelijken niet acceptabel zijn. Omdat de wet geen belemmeringen opwerpt tegen kinderhuwelijken in de informele sfeer, zullen deze gesloten kunnen blijven worden onder het regime zoals dit ook voorheen gold. Een positief effect van de wet is dat kindbruiden die beneden de leeftijd van 18 jaar naar Nederland komen, in alle gevallen de bescherming van jeugdzorgautoriteiten kunnen krijgen. 